\title{
Slope stability analysis at Siilinjärvi Mine
}

\author{
S. Mononen Yara Suomi Oy, Finland \\ H. Kuula Pöyry Finland Oy, Finland \\ M. Lamberg Pöyry Finland Oy, Finland
}

\begin{abstract}
Siilinjärvi phosphate mine in eastern Finland has been in operation as an open pit since 1979. The current main pit, the Särkijärvi open pit, is 2,900 $\mathrm{m}$ in length, $235 \mathrm{~m}$ in depth and at its widest part $750 \mathrm{~m}$ wide. The ore feed to the mill is close to $11 \mathrm{Mt} /$ a. The stripping ratio in current LOM (mine life to 2034) is on average 0.6 but a major extension program is ongoing and for the next nine years the stripping ratio will be around 1.2. Part of the main pit extension program involves new infill drillings, altogether $39 \mathrm{~km}$ in 2012-14. The updated geological and rock mechanics data is and will be used in slope stability analysis. Engineering company Pöyry Finland $\mathrm{Oy}$ is developing rock mechanics analyses and delivering guidance's to the mine engineering team.
\end{abstract}

The Siilinjärvi carbonatite complex is a steeply dipping Archean vein intrusion that has intruded into granite gneiss. The complex is approximately $16 \mathrm{~km}$ long. The main rock types are calcite carbonatite, glimmerite and their varieties depending on the amount of apatite and calcite. The carbonatite is surrounded by a fenite halo. The geology in the mine is challenging as seen from a rock mechanics perspective. The glimmerite rock has poor rock quality and a low uniaxial compressive strength. The glimmerite has a similar major joint direction as the intrusion general strike and dip which is noted as a weakness plane for the rock mass. The glimmerite rock mass was partly highly sheared due to late/post intrusion tectonics. The shear zones consist of an extremely weak rock mass and have high water loss values.

Geotechnical characterisation of the rock mass has been carried out using $Q$ - and GSI systems. The rock quality was mapped directly from the open pit walls and from drill holes. Also 3D-photogrammetry was used to map joints and shear zones in the pit.

The stability analysis was performed using the distinct element program, 3DEC. The rock mass was modelled as a Mohr-Coulomb elastic, perfectly plastic continuum. Analysis used a shear strength reduction approach: the shear strength envelope of material was reduced by a Factor of Safety until the velocities in the model are not balanced. Because of limited groundwater data simulations were made with drained and almost fully saturated conditions.

The lowest safety factor was found to be in the weak rock mass area where the safety factor for overall stability was 1.6 in saturated slope and about 1.9 in drained slope. In individual benches the lowest safety factors varied from $<1$ to 1.2. For the detailed parametric study $2 D$ analysis was also made with Phase 2. The cross section was taken through the middle part of the open pit. In $2 D$ analysis the extent of the disturbance zone and groundwater table was studied.

The stability analysis was performed in order to identify potentially unstable areas. From those areas collection of groundwater data will be substantially increased. Also additional geotechnical core logging and mapping will be executed. To monitor the stability of the open pit, purchasing of slope stability radar is under consideration by the mine.

In 2013 the extension of the open pit will be analysed with 3DEC. After completion of the drilling program in 2014, new open pit optimisation will be carried out; at the same time the geotechnical study will be updated using 3DEC. 


\section{Siilinjärvi phosphate mine}

Siilinjärvi phosphate mine in eastern Finland has been in operation as an open pit since late December 1979. The current main pit (Figure 1), the Särkijärvi open pit, is 2,900 $\mathrm{m}$ in length, $235 \mathrm{~m}$ in depth and at its widest part $750 \mathrm{~m}$ wide. The ore feed to the mill is close to $11 \mathrm{Mt} / \mathrm{a}$. The stripping ratio in current LOM is on average 0.6 but a major extension program is ongoing in the main pit and for the next nine years the stripping ratio will be around 1.2 .

The current pit design parameters are: overall slope angle $46-52^{\circ}$, bench height $28 \mathrm{~m}$ (double $14 \mathrm{~m}$ benches), batter angle $72^{\circ}$, berm width $14 \mathrm{~m}$, ramp grade $1: 10$, ramp width $35 \mathrm{~m}$. The parameters will be re-evaluated in 2014 when there is large amount of updated data for re-optimisation of the main pit.

In 2013 the production areas of the main pit are in the southwest, west and northwest cutbacks and in 2014 mining will also start in the east extension

In September 2012 a small satellite open pit was opened about $5 \mathrm{~km}$ north from the main pit. The satellite pit is budgeted to give $25 \%$ of ore feed to the same primary crusher and concentrator plant for the next 10 years, i.e. $75 \%$ of ore feed during this time is trucked from the main pit. This paper considers only the slope stability of the main pit.

Part of the main pit extension program comprises new infill drillings, altogether $39 \mathrm{~km}$ in 2012-14. The updated geological and rock mechanical data is and will be used in slope stability analysis. He engineering company Pöyry Finland Oy is developing rock mechanics analyses and delivering guidance's to the mine engineering team.

In the 34 year history of the mine there have been several bench scale failures but also some multi-bench scale failures. The former have been typically wedge type failures on the west side of the main pit (Figure 5) and the latter planar failures in the eastern pit wall due to a major shear zone (Figure 7). During 2013, for safety reasons, the mine will acquire real-time slope monitoring radar.

The mine started in 2012 a large rock mechanics program which includes new infill drillings including rock mechanics characterisation, 3D-photogrammetry for geotechnical mapping, groundwater measurements for the planning of drainage holes, 2D and 3D simulations for slope stability analysis.

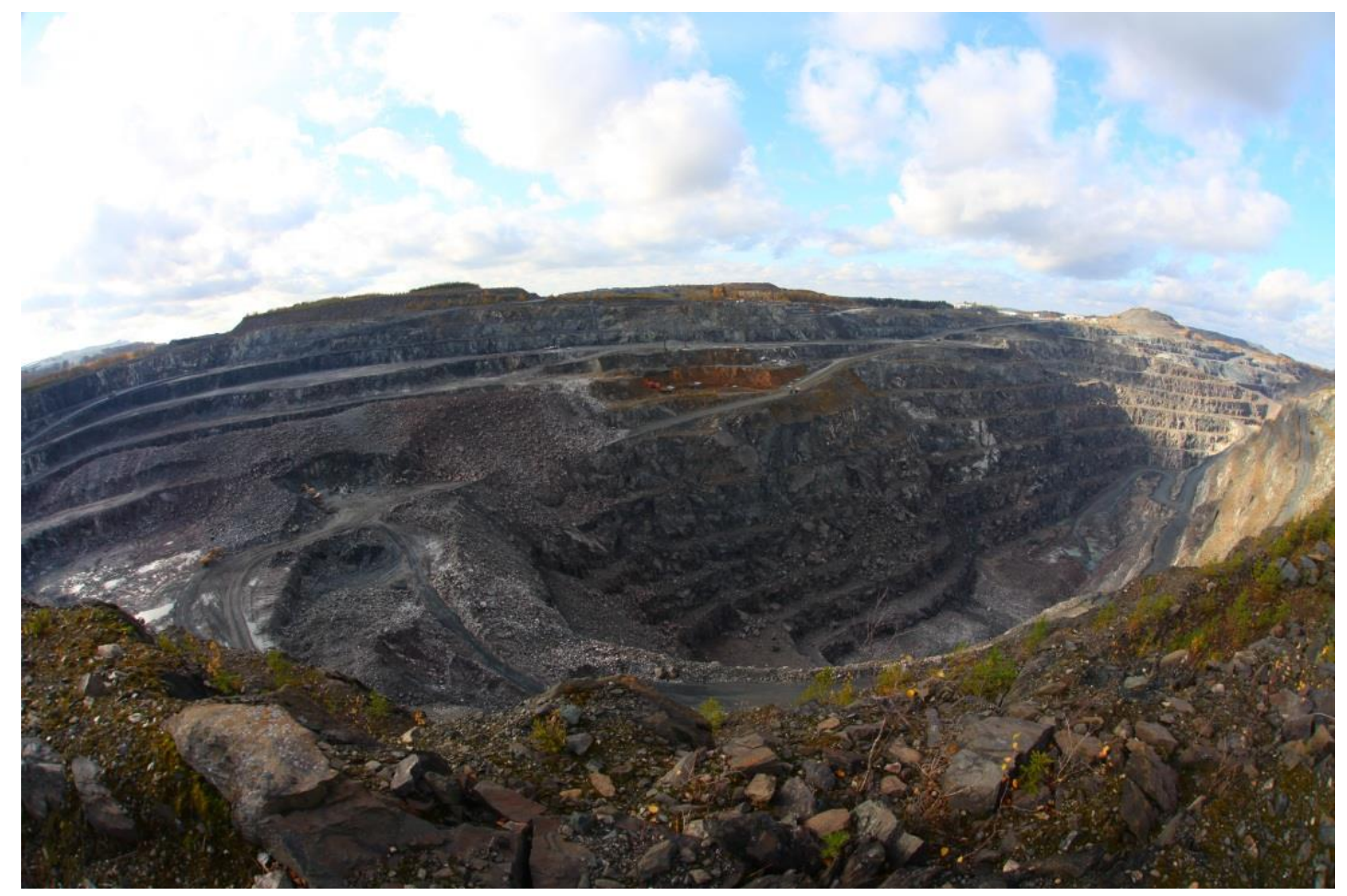

Figure 1 The main pit of Siilinjärvi mine in April 2013. F = 8, $15 \mathrm{~mm}$ fish eye objective 


\section{Geology}

The Siilinjärvi carbonate complex is a 2.6-2.8 Ga old late Archean vein intrusion (Härmälä, 2002). It is located in the Archean granite - gneiss area in eastern part of Finland. The complex is approximately $16 \mathrm{~km}$ long along strike and $700 \mathrm{~m}$ wide at its widest parts and dipping $70-90^{\circ}$ to the west. The complex has been intersected at $800 \mathrm{~m}$ depth and is known to be open at depth (Härmälä, 2002).

The complex is surrounded by granite gneiss and diorite and comprises mostly carbonate rocks with a fenite halo surrounding it. The fenite halo indicates that contact metamorphism has occurred in the older granite rocks during and post intrusion stages (Figure 2).

The intrusion is known to have occurred in several stages during the eruption period. Multiple fluid rich magma pulses have brought the carbonate, magnesium, potassium and phosphorus rich magma close to the ground surface through a narrow fracture zone. The magmas element content was known to vary between different intrusion phases resulting in multiple zones of varying carbonate content (Kauppinen, 1988).

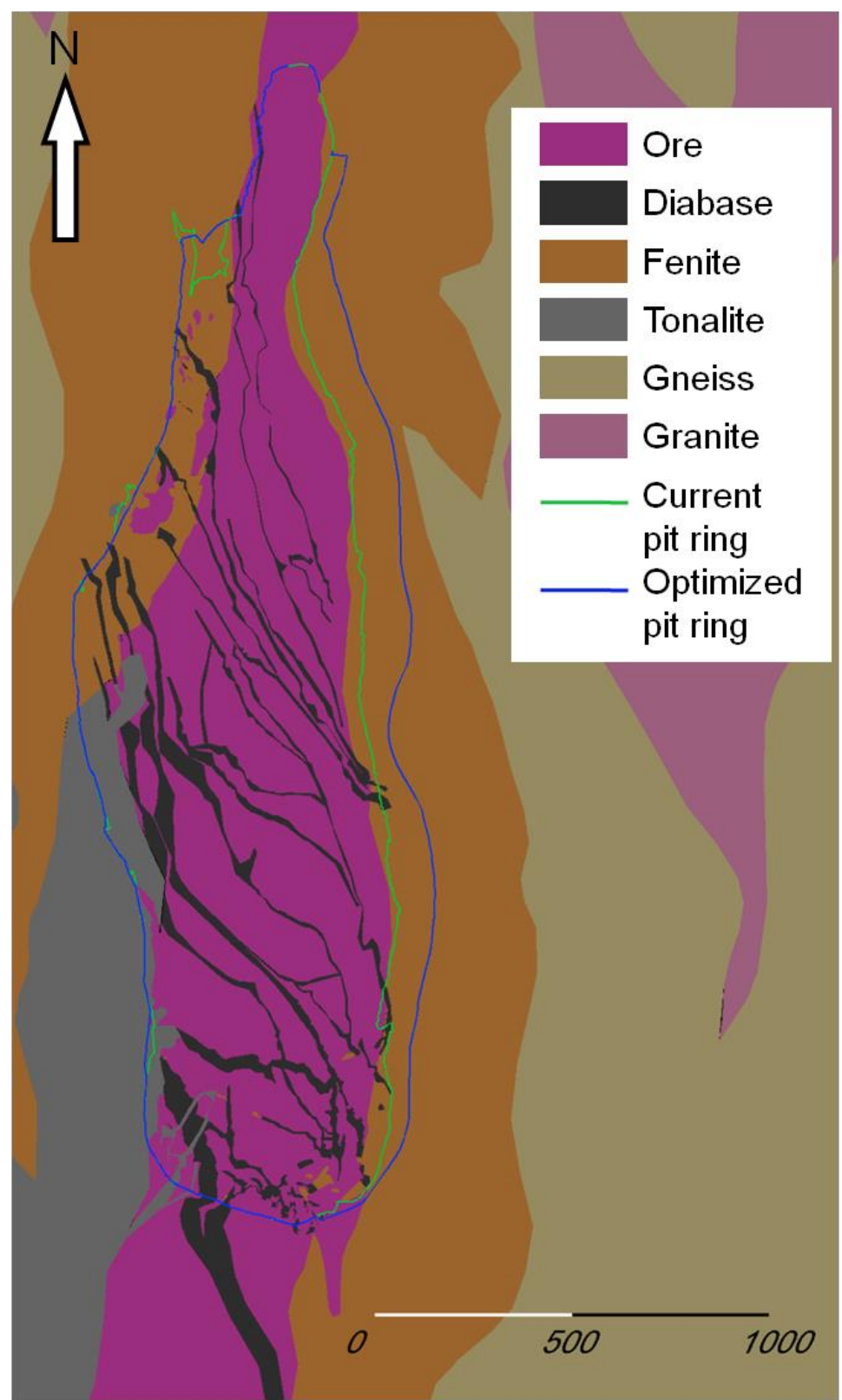

Figure 2 The Siilinjärvi carbonatite complex. Current main pit is located in the middle of the complex at the widest part of the carbonatite (Heino, 2012) 


\subsection{Apatite ore}

The ore occurrence consists mostly of a glimmerite-carbonate series of rocks (Table 1). The desired mineral for production is apatite. The carbonatite is classified as an ore when the cut off of approximately $3 \%$ of $\mathrm{P}_{2} \mathrm{O}_{5}$ is reached. The ore is mineralogically simple starting from pure mica rock, glimmerite (schist), changing to more carbonate rich rock, carbonate-glimmerite and finally to pure calcite carbonate rock (Vartiainen, 1998). According to Puustinen (1971) the glimmerite-carbonate rocks occur irregularly with thickness varying from centimetres to tens of meters. The complex is known to be more rich in carbonate and phosphor at the centre parts (along strike) of the complex and poor in carbonate and $\mathrm{P}_{2} \mathrm{O}_{5}$ at the sides adjacent to the fenite halo. The complex is also intersected by younger dioritic and diabase southeast-northwest trending veins.

\section{Table 1 The apatite ore according to amount of carbonate minerals}

\begin{tabular}{cc}
\hline Rock & Amount of Carbonate Minerals (\%) \\
\hline Glimmerite & $0-10 \%$ \\
Carbonate-glimmerite & $10-25 \%$ \\
Silikosövite & $25-50 \%$ \\
Sövite & $50-100 \%$ \\
Apatite glimmerite & $15-25 \%$ of apatite \\
Apatite rock & $>25 \%$ of apatite \\
\hline
\end{tabular}

\subsection{Groundwater}

The location of the carbonatite complex and the mine results in a high groundwater level. Nearby lakes have a similar water level as the ground level in the mining area. Because of the lakes and fractured rock mass the groundwater level is known to be high even close to the open pit. Recent measurements revealed that the water table is $2-15 \mathrm{~m}$ below ground surface in and around the open pit.

The groundwater level is continuously monitored to record the seasonal highs in the water table. In Figure 3 is shown a part of the collected groundwater data from just outside the open pit rim. Monitoring points locate both in west and east side of the open pit. The seasonal variation is seen from the measurements. Similar measurement results are gained in the open pit (access ramps and production levels).

\begin{tabular}{|c|c|c|c|c|c|c|c|c|c|}
\hline 0 & & & & & & & & & \\
\hline & & & & & & & & & \\
\hline & & & & & & & & & \\
\hline und surface & & & & & & & & & \\
\hline 10 & - & --- & $--1=$ & $\Rightarrow$ & ene= & $=12$ & -- & --- & $-\ldots$ \\
\hline 12 & \begin{tabular}{|l|}
24.9 .2012 \\
\end{tabular} & 3.10 .2012 & 2.11 .2012 & 30.1 .2013 & 26.2.2013 & 28.3.2013 & 19.4 .2013 & 22.4 .2013 & 21.5.2013 \\
\hline--- West & $8.55 \mathrm{~m}$ & $9.37 \mathrm{~m}$ & $10.24 \mathrm{~m}$ & $10.9 \mathrm{~m}$ & $10.93 \mathrm{~m}$ & $10.95 \mathrm{~m}$ & $6.42 \mathrm{~m}$ & $6.625 \mathrm{~m}$ & $6.83 \mathrm{~m}$ \\
\hline--- West & $11 \mathrm{~m}$ & $11.01 \mathrm{~m}$ & $11.02 \mathrm{~m}$ & $11.14 \mathrm{~m}$ & $11.15 \mathrm{~m}$ & $11.17 \mathrm{~m}$ & $11.16 \mathrm{~m}$ & $11.16 \mathrm{~m}$ & $11.16 \mathrm{~m}$ \\
\hline--- West & $8.75 \mathrm{~m}$ & $8.7 \mathrm{~m}$ & $9.31 \mathrm{~m}$ & $9.75 \mathrm{~m}$ & $9.75 \mathrm{~m}$ & $9.77 \mathrm{~m}$ & $9.72 \mathrm{~m}$ & $8.68 \mathrm{~m}$ & $7.64 \mathrm{~m}$ \\
\hline East 1 & $0 \mathrm{~m}$ & $0.2 \mathrm{~m}$ & $1.34 \mathrm{~m}$ & $2.4 \mathrm{~m}$ & $1.88 \mathrm{~m}$ & $3.54 \mathrm{~m}$ & $2.27 \mathrm{~m}$ & $1 \mathrm{~m}$ & $1.46 \mathrm{~m}$ \\
\hline$\longrightarrow$ East 2 & $7.75 \mathrm{~m}$ & $7.15 \mathrm{~m}$ & $8.08 \mathrm{~m}$ & $10.89 \mathrm{~m}$ & $11.32 \mathrm{~m}$ & $11.35 \mathrm{~m}$ & $9.04 \mathrm{~m}$ & $8.495 \mathrm{~m}$ & $7.95 \mathrm{~m}$ \\
\hline$\longrightarrow$ East 3 & $9.3 \mathrm{~m}$ & $9.3 \mathrm{~m}$ & 10.36 m & 10.46 m & $10.5 \mathrm{~m}$ & $10.53 \mathrm{~m}$ & $3.98 \mathrm{~m}$ & $7.03 \mathrm{~m}$ & $10.08 \mathrm{~m}$ \\
\hline East 4 & $4.4 \mathrm{~m}$ & $4.3 \mathrm{~m}$ & $5.03 \mathrm{~m}$ & $6.6 \mathrm{~m}$ & $7.02 \mathrm{~m}$ & $7.73 \mathrm{~m}$ & $5.29 \mathrm{~m}$ & $5.28 \mathrm{~m}$ & $5.27 \mathrm{~m}$ \\
\hline
\end{tabular}

Figure 3 The seasonal variation in the groundwater levels at the open pit rim 


\section{Geotechnical characterisation}

Before rock mechanics analyses were initiated there was sparse and relatively old rock mechanics data available. Because of the amount of planned rock mechanics analyses it was decided to start comprehensive geotechnical core logging by the Yara's geologists. Open pit wall logging was commenced by Pöyry geologists.

For the first rock mechanics analyses it was decided to carry out the geotechnical mapping directly from the open pit walls to gain first hand initial data. The geotechnical characterisation of the rock mass was carried out using the $Q$ - and GSI systems in addition to RMR. Mapping was undertaken on the open pit walls during dry and wet periods. Side by side mapping using the Q - and GSI systems provided the opportunity for subsequent comparison of results.

No drill cores were available during the mapping period so there was no opportunity to compare results between the pit wall mapping and the core mapping results. The old cores were cut in the past using a guillotine or rock core saw. Some drill cores were still available for laboratory tests to determine the uniaxial compressive strength.

The goal of the open pit mapping was to create a simplified rock quality map for the open pit that would be useful in future numerical simulations (Figure 4). The idea was to map major faults and shear zones that could cause stability issues in the pit walls. It was previously known that the deposit had experienced post intrusion tectonics and there were many observations of major shear zones in the open pit area. Large shear zones were located in multiple separate zones both in the east and west pit walls. Shear zone thicknesses were ranging from $1 \mathrm{~m}$ up to $20 \mathrm{~m}$.

The shear zones containing low friction joint surfaces have caused stability issues in the east open pit wall mostly in size of one or two bench scale. Similar issues have been noted in the west open pit wall but in less extend. In the northeast part of the open pit the major shear zone has caused multiple bench scale pit failures (Figures 5-7).

As result of the open pit mapping average GSI values for the different rock types were calculated although it was noted that the rock quality varies also inside the rock type classes (Table 2).

Table 2 The average GSI values by rock type

\begin{tabular}{cc}
\hline Rock Type & GSI Value \\
\hline Glimmerite (class 1) & 51 \\
Glimmerite weak (class 2) & 35 \\
Carbonate-glimmerite & 65 \\
Shear zone in glimmerite & 21 \\
Fenite & 70 \\
\hline
\end{tabular}

The overall rock quality in the open pit varies from extremely poor to very good (Figure 4). The carbonate-glimmerite has rock quality of good or very good. As carbonate-glimmerites exist in the middle of the carbonatite complex/open pit, it has minor effect on the open pit wall stability. Most of the open pit walls consist of glimmerite rocks that have rock quality varying from poor to good excluding shear zones (glimmerite) that have rock quality of extremely poor to poor. The fenite has rock quality from good to very good. The fenite has only a minor effect on the pit wall stability as it occurs mainly outside of the open pit. In some parts of the pit there are fenite xenoliths seen in the glimmerite matrix. A mixture of xenoliths and glimmerite has caused some smaller bench scale stability problems. The glimmerite schist consists mostly of mica (phlogopite) that occurs in euhedric shape of sheets. The glimmerite has planes of weakness due to its slaty or sheet type texture that is the dominant structural direction, (north-south strike) observed within the whole deposit. 


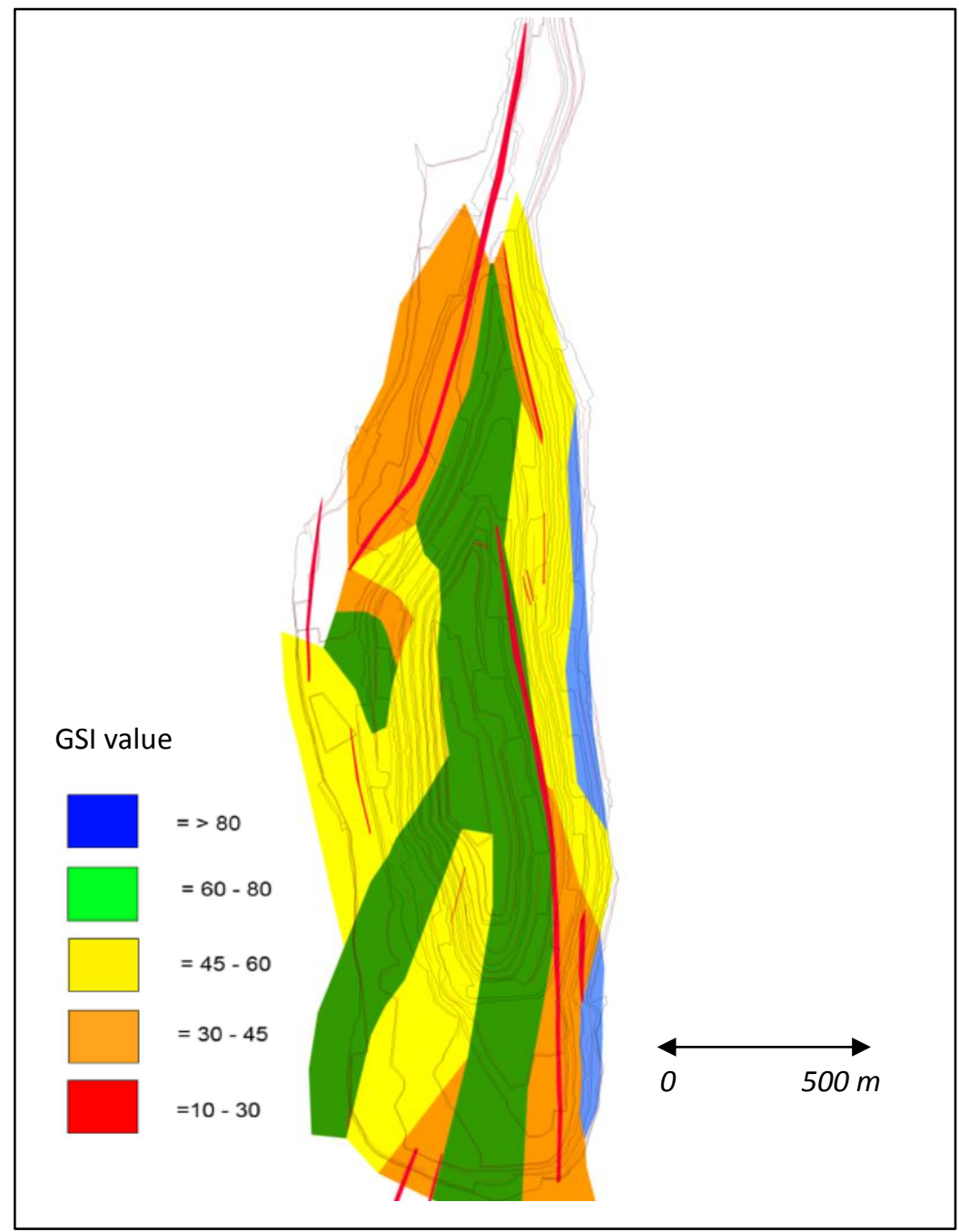

Figure 4 Simplified rock quality map of the Särkijärvi open pit

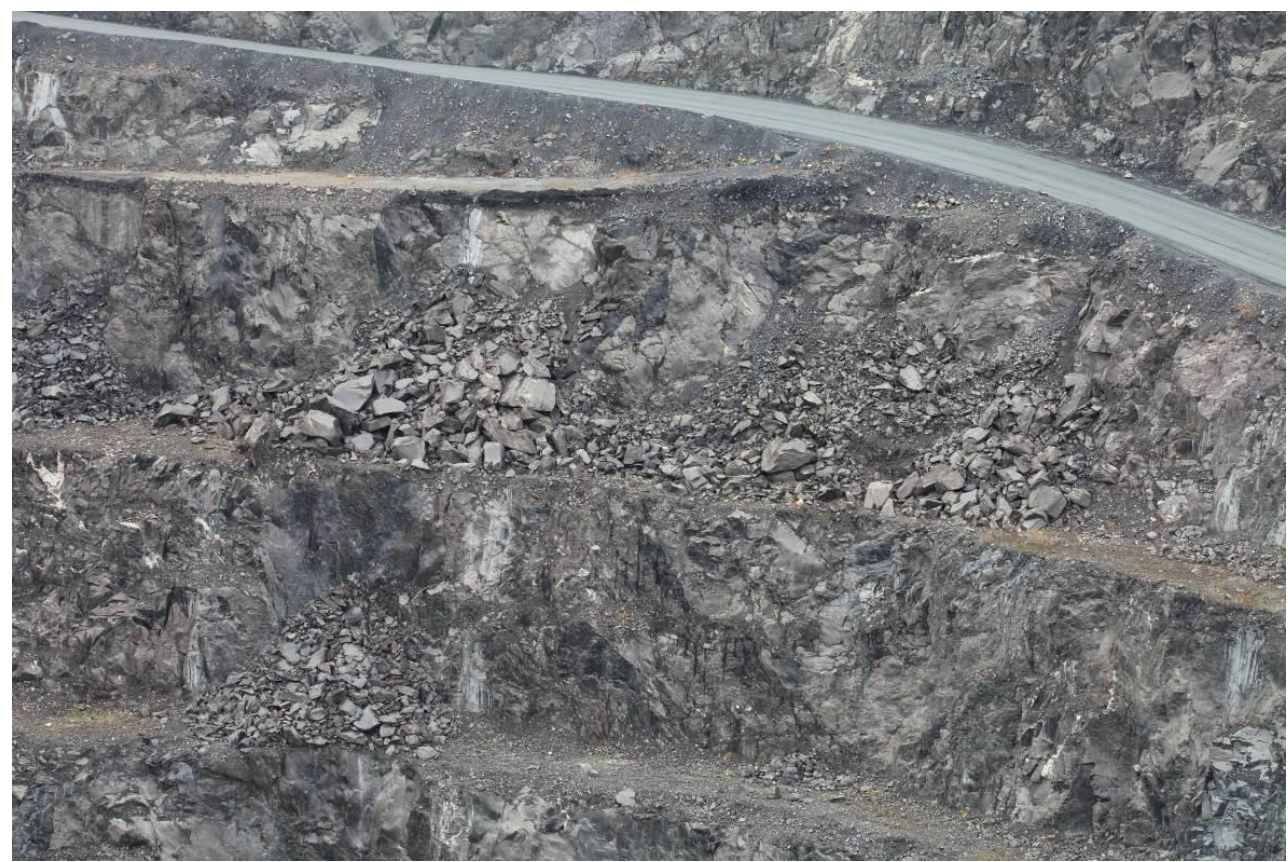

Figure 5 Wedge type failures in northwest - part of the main pit 


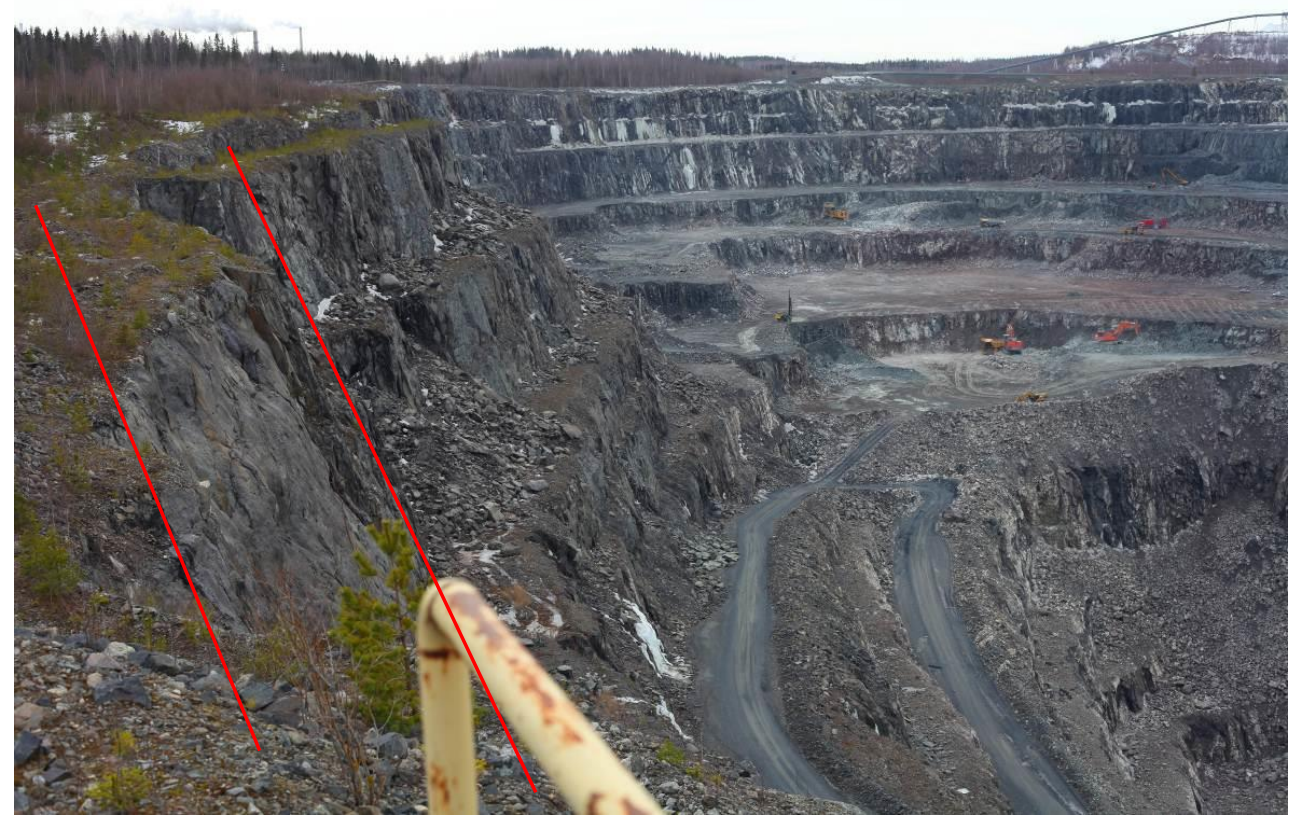

Figure 6 Planar type failure in east pit wall. Most of the shear zone has collapsed

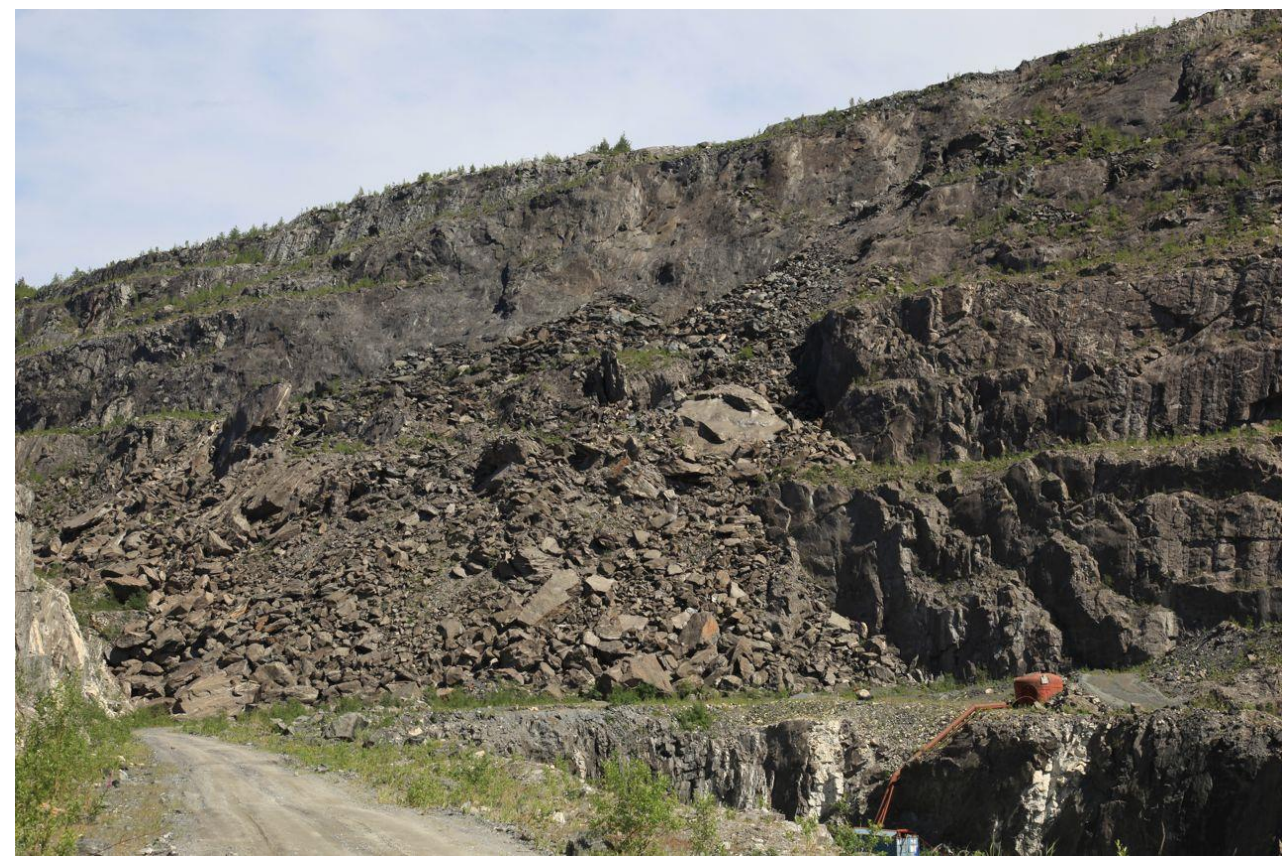

Figure 7 Pit wall failure (April 2002) in northeast - part of the main open pit caused by the major shear zone in the east wall

\subsection{D-photogrammetry}

To aid geotechnical mapping the whole open pit was photographed using 3D-photogrammetry method by Adam Technology. A relatively quick method for mapping gave a good understanding of the pit wall geology and the rock quality. The pit was photographed before the geotechnical mapping in the pit was commenced providing geologists a good overall picture of the pit before mapping (Figures 8-9).

From the 3D-models major shear zones and fractures were digitised and exported to mining software GEOVIA Surpac (GEOVIA, 2013). Using the 3D-models distinctive rock quality regions were established by visually estimating the rock texture, fracture number, previous bench failures and water seepage. The digitised regions were then used in the field to assist geotechnical mapping of the rock mass. 
Using the 3D-models it was clearly noted that carbonate rich rocks had better rock quality, lower water seepage amounts and lower number of previous bench failures than the carbonate poor glimmerite rocks. It was also noted that most of the shear zones occurred in the glimmerite rocks. A general dip and dip direction for joints was also mapped from the 3D-models. The general joint dip was varying between $70-90^{\circ}$ dipping to the west or to the east and having the same strike direction as the foliation direction of the deposit (Figure 10). The major joints including continuum information were imported to the 3DEC analysis models.

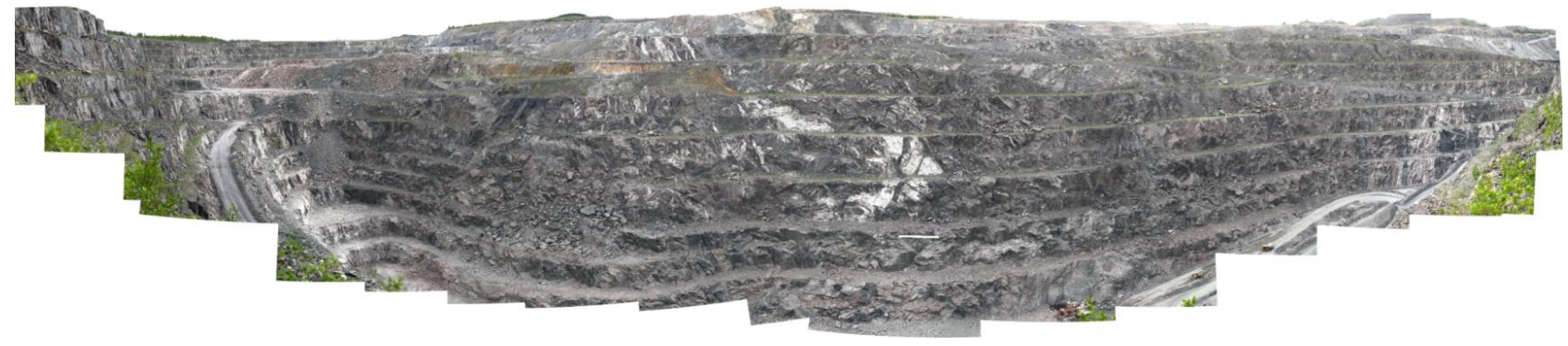

Figure 8 The Särkijärvi open pit west wall. A panorama of multiple photos, $f=8,100 \mathrm{~mm}$ objective. Length of the area in picture approximately $2.5 \mathrm{~km}$ (left to right end)

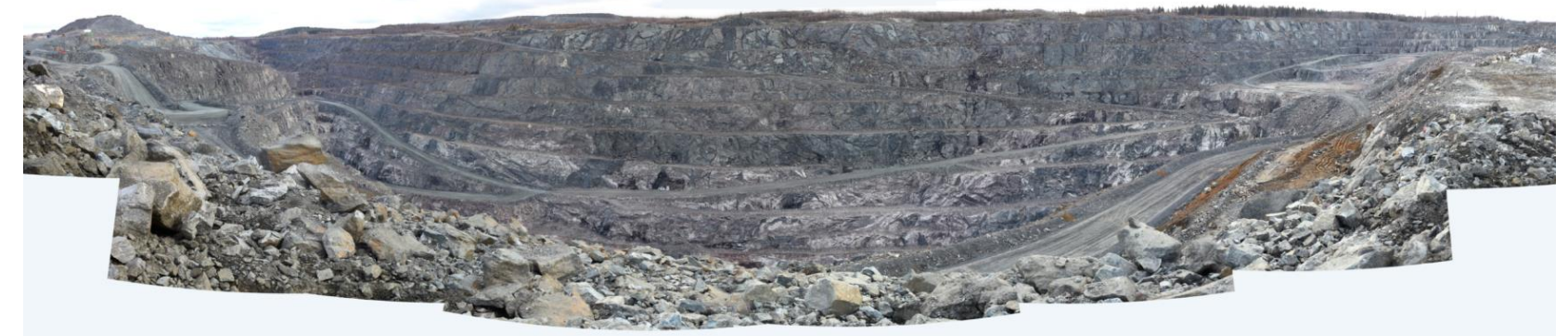

Figure 9 The Särkijärvi open pit east wall. A panorama of multiple photos, $f=8,70 \mathrm{~mm}$ objective. Length of the area in picture approximately $3 \mathrm{~km}$ (left to right end)

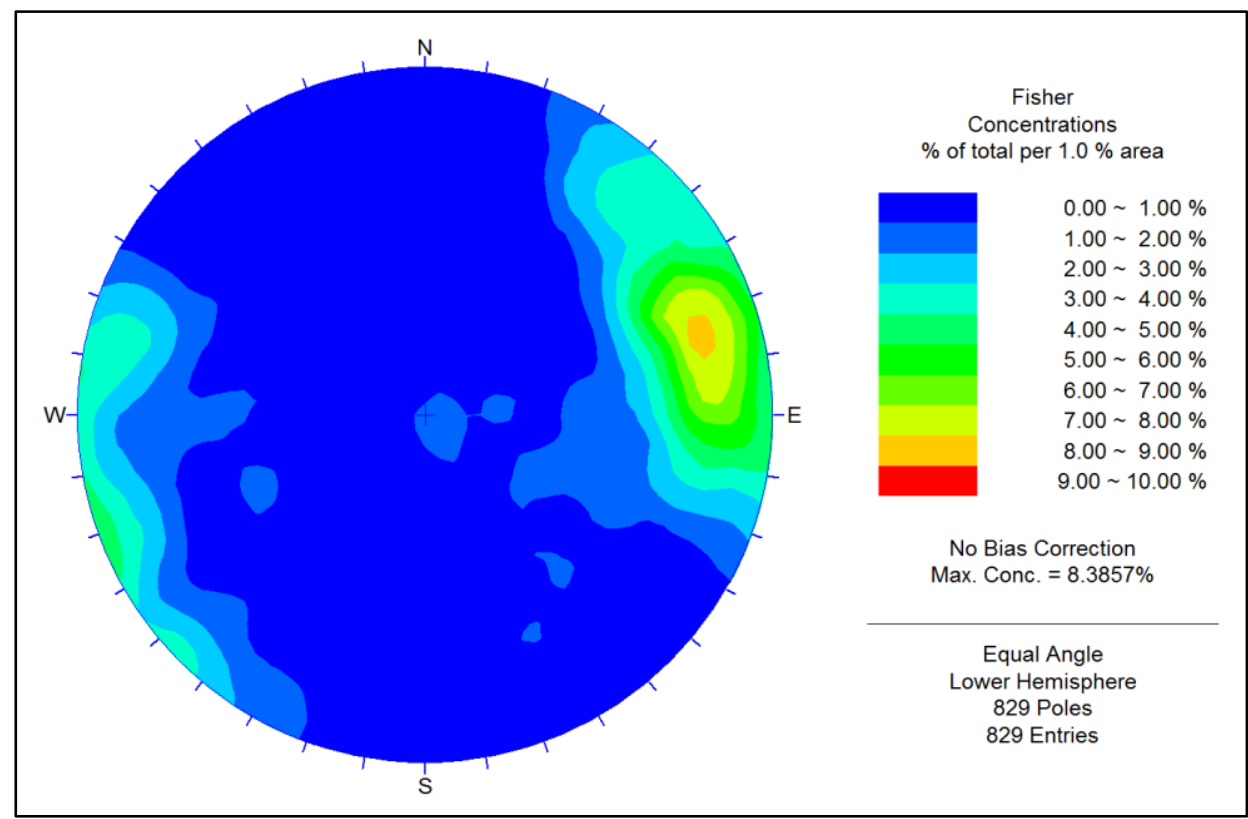

Figure 10 A lower hemisphere projection showing average dip and dip direction in the open pit 


\section{$4 \quad$ Slope stability analyses}

Slope stability analysis was performed in two stages. Preliminary analysis was undertaken with Phase 2 . The influence of the assumed GSI value, the effect of different groundwater levels and extent of the disturbance zone were all analysed.

The cross section of the simulation was from the deepest point of the open pit. The uniaxial compressive strength of intact rock was $55 \mathrm{MPa}$ and mi value was 22. The Uniaxial compressive strength test samples were collected from few drill holes around the open pit. In the disturbed area the disturbance factor (D) was 1. The safety factor versus GSI value and ground water level is shown in Figure 11. The effect of GSI value was studied in the Phase 2 analysis. In the 3DEC analysis the different GSI values were based on distinct rock quality regions see Figure 4 . The base case parameters for Phase 2 analysis are shown in Table 3.

Table 3 The base case rock mass parameters for phase 2 analysis

\begin{tabular}{ccc}
\hline Rock Mass Parameter & $\begin{array}{c}\text { Intact Rock Mass } \\
\text { Parameters D = 0 }\end{array}$ & $\begin{array}{c}\text { Disturbed Rock Mass } \\
\text { Parameters D = 1 }\end{array}$ \\
\hline GSI & 47 & 47 \\
Uniaxial compressive strength & 55 & 55 \\
Cohesion (MPa) & 0.9 & 0.49 \\
Friction angle $\phi\left(^{\circ}\right)$ & 52.1 & 36.2 \\
Tension $\sigma(\mathrm{MPa})$ & 0.046 & 0.016 \\
Young's modulus (GPa) & 7.6 & 1.7 \\
mi & 22 & 22 \\
\hline
\end{tabular}

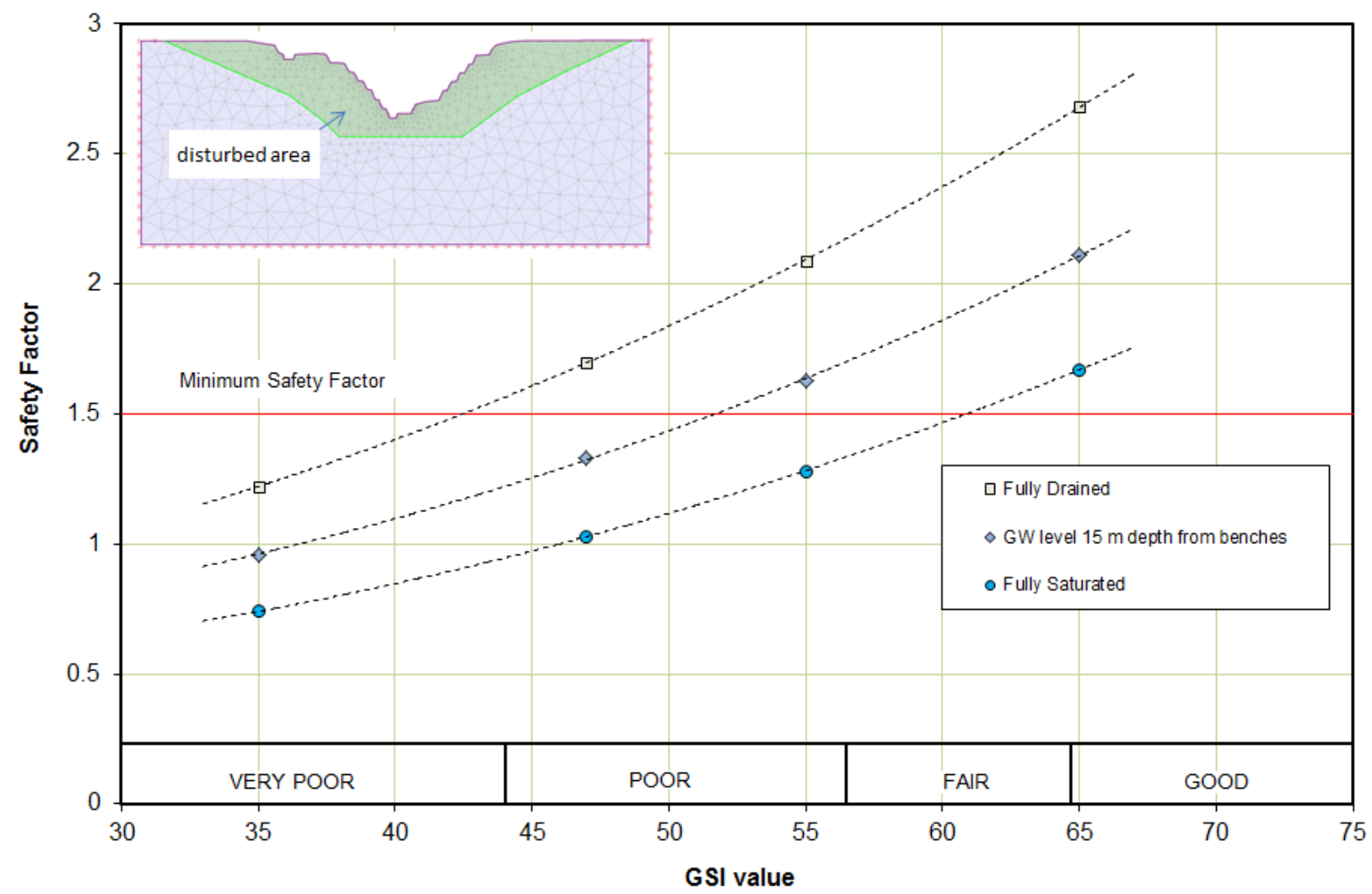

Figure 11 Safety factor versus GSI value with different ground water conditions 
The Phase 2 analysis were performed as a non disturbed rock mass model and fully disturbed rock mass model and their varieties (Figure 12). The base case analysis were performed using disturbed area that extens up to $150 \mathrm{~m}$ to the rock wass from the pit walls.
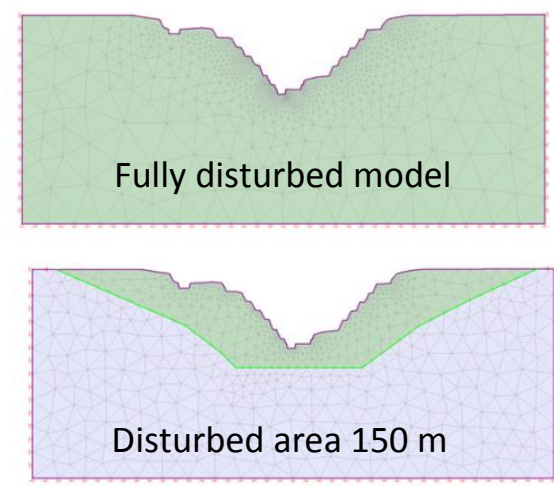
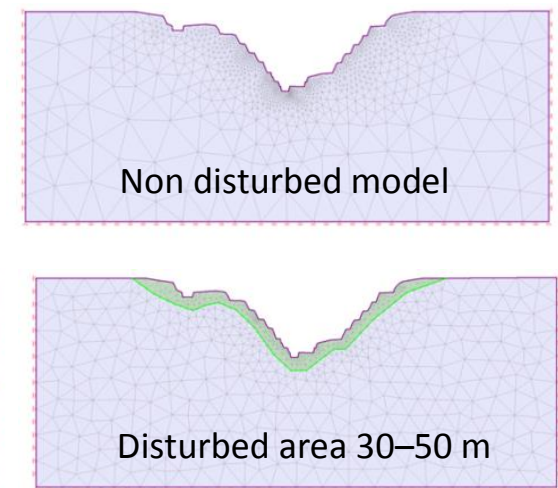

Figure 12 The disturbed areas in the Phase 2 models. Dark area is the disturbed area $D=1$. Light area is the non-disturbed area $D=0$

\subsection{DEC simulation model}

After preliminary study, the stability analysis was performed using the distinct element program, 3DEC. The 3DEC model geometry was initially taken from Yaras mining software (GEOVIA Surpac). The Särkijärvi open pit is measured daily with new production blast regions and the pit geometry updated. The latest pit geometry was triangulated and irregularities edited. The triangulated pit geometry was then transferred to the 3DEC code using a developed Excel macro. The 3DEC model geometry was in real mine coordinates and in realistic shape.

The rock mass was modelled as a Mohr-Coulomb elastic, perfectly plastic continuum. Analysis was undertaken using a shear strength reduction approach: the shear strength envelope of material was reduced by a factor of safety until the velocities in the model are no longer balanced. As limited groundwater data was available simulations were made assuming drained and almost fully saturated conditions.

The variable rock mass parameters were imported to the 3DEC model using distinct Dxf-file regions to assist parameters to the plastic Mohr-Coulomb zone model. This method gained the advantage to assist as many as desired rock mass property regions to the model. The rock mass parameters were set according to the GSI rock quality regions in Figure 3.

In the 3DEC model the disturbed area extends up to $150 \mathrm{~m}$ away from the open pit. This was decided according to the Phase 2 analysis.

The lowest safety factor was found to be in the weak rock mass area where safety factor for overall stability was 1.6 for the saturated slope and approximately 1.9 for the drained slope. The lowest Factor of Safety area was in the southwest open pit area that has previously had minor bench failures. For individual benches the lowest safety factors varied from $<1$ to 1.2. In Figure 13 is shown the initial failures in drained conditions after strength reduction (safety factor of 1.6) and further developed overall slope failures after additional strength reduction (safety factor of 2). Cross section (A) of the overall slope failures is shown in Figure 14. 

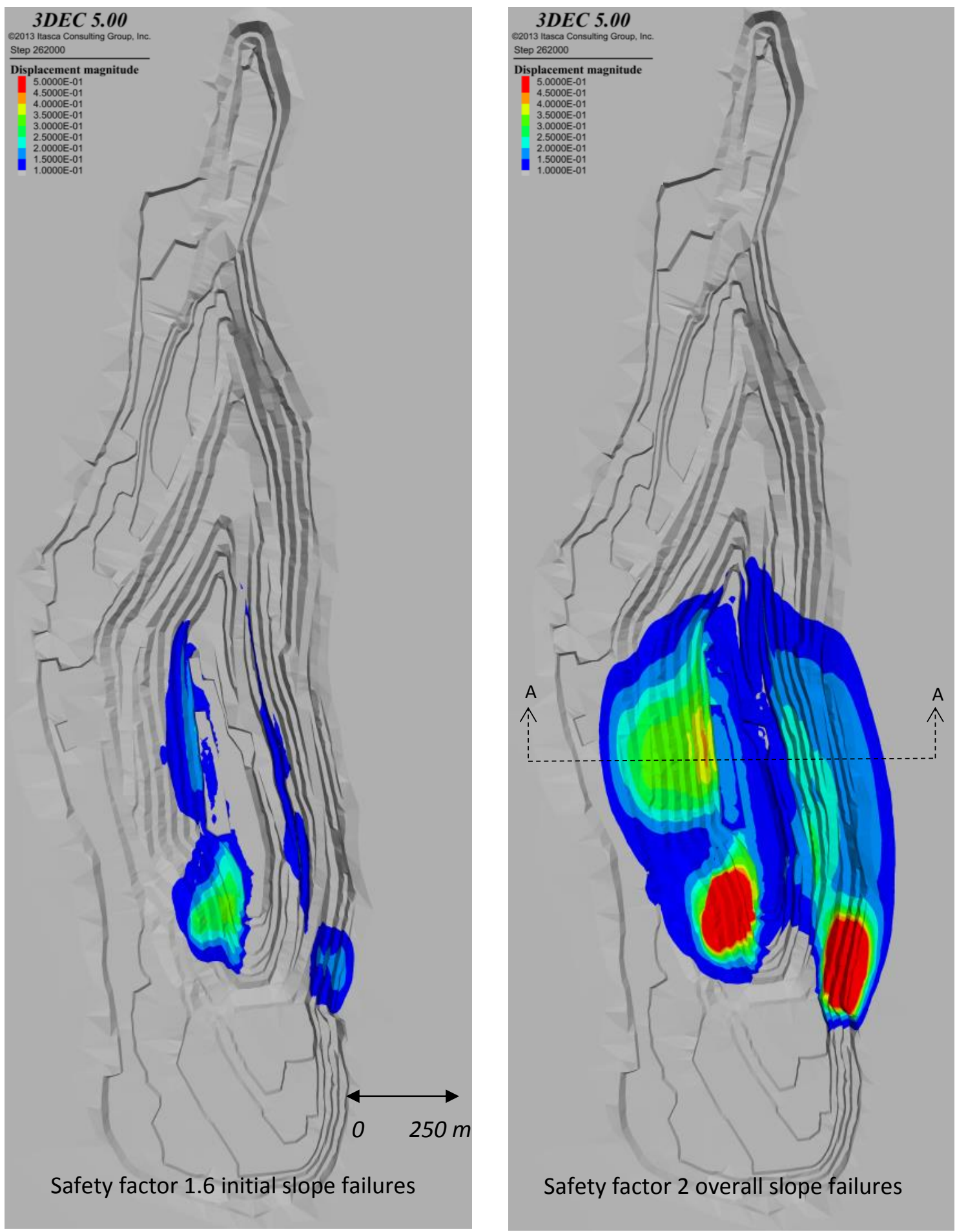

Figure 13 Simulated failed areas in 3DEC in drained conditions. The initial failed areas after strength reduction are seen in the left image. Further developed failures are seen on the right image. The velocities are no longer balanced therefore the amount of displacements is crowing in non-balanced areas 


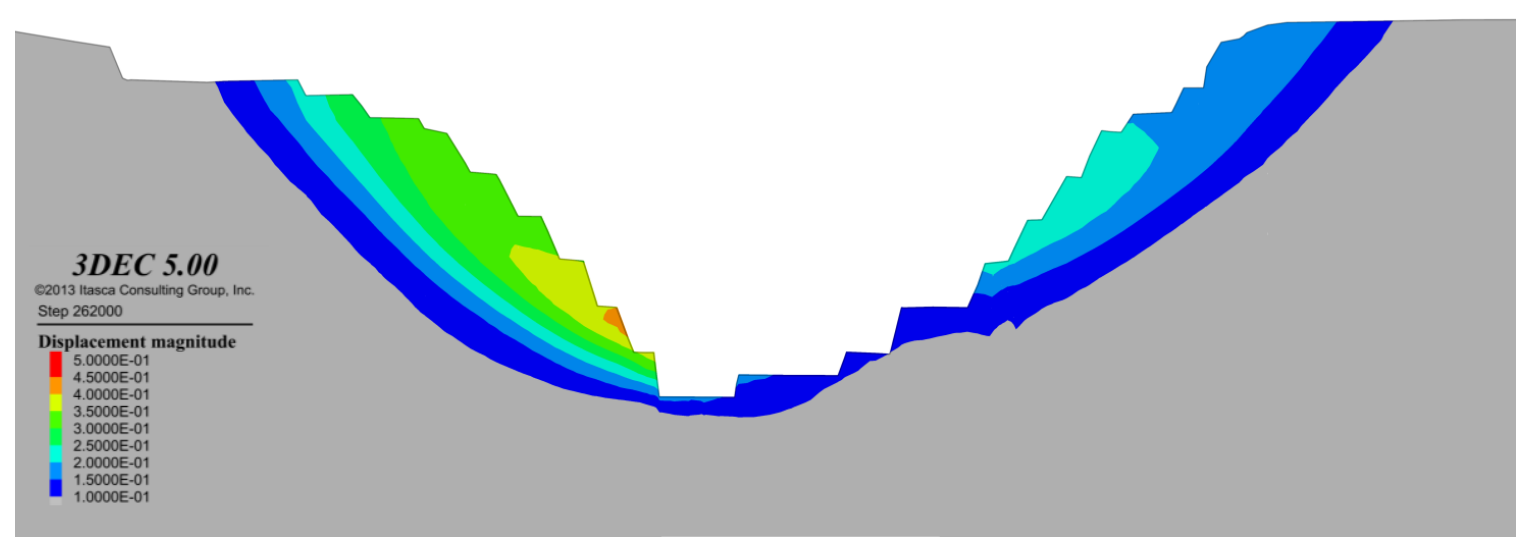

\section{Figure 14 Cross section A-A of the open pit after overall slope failure. The velocities are no longer balanced in areas where displacements are greater than 15-20 cm}

The stability analysis was performed in order to identify potential unstable areas. Most of the unstable areas were related to the weak rock mass and unfavourable pit wall geometry. Initial failures in the open pit were noted in the vicinity of the shear zones or directly in the shear zones.

The unstable areas are recommended to be access restricted areas especially in high rain fall seasons. The unstable areas are also mined with caution when the mine extension reaches those areas.

In the weak rock mass areas the open pit wall design is made with reduced overall pit slope angle and with favourable geometry. The southwest and southeast areas of the pit are the most critical pit areas with the initial failures at safety factor of 1.6 in drained conditions. This is due to the weak rock mass and convex open pit wall geometry. The southwest and southeast pit wall geometries are straightened in the final open pit design and the overall pit slope angle is reduced from $48^{\circ}$ to $46-44^{\circ}$ to increase stability. The unstable slope areas are also partially drained from groundwater and collection of groundwater data will be substantially increased.

Additional geotechnical core logging and mapping will be executed for more detailed rock quality study. Joint dip and dip directions are added regionally in future 3DEC analysis.

To monitor the stability of the open pit, purchasing of slope stability radar is under consideration by the mine. The primary monitored areas are the west pit wall areas that are indicated as unstable in the simulations.

In 2014 the extension of the open pit will be analysed with 3DEC. After completion of the drilling program in 2014 a new open pit optimisation study will be carried out. At the same time the geotechnical study will be updated with 3DEC.

\section{References}

GEOVIA (2013) Surpac, Geological Modelling, Mine Planning and Surveying software, http://www.gemcomsoftware.com /products/surpac.

Heino, P. (2012) Geology of the Siilinjärvi Carbonatite Complex, Yara's internal presentation of the mine area geology.

Härmälä, O. (2002) Siilinjärvi carbonatite complex and apatite mine, Talc-magnesite deposits in Finland, third field correlation, 43 p. Kauppinen, H. (1988) Siilinjärvi Apatite deposit. Industrial minerals and rocks in Finland, in Finnish, pp. 43-46.

Puustinen, K. (1971) Geology of Siilinjärvi carbonatite complex, Eastern Finland, Bulletin of The Geological Society of Finland, The Geological Society of Finland, No. 249, 42 p.

Vartiainen, H. (1998) The Alkaline rocks in Finland, The Bedrock of Finland, 3000 million years, The Geological Society of Finland, in Finnish, pp. 285-325. 